Ambiente \& Água - An Interdisciplinary Journal of Applied Science
ISSN 1980-993X - doi:10.4136/1980-993X
www.ambi-agua.net
E-mail: ambi.agua@gmail.com

\title{
Relationship between land use and water quality in a watershed impacted by iron ore tailings and domestic sewage
}

\author{
ARTICLES doi:10.4136/ambi-agua.2383
}

Received: 22 Feb. 2019; Accepted: 06 Aug. 2019

\author{
Laura Pereira do Nascimento ${ }^{1 *}$; Deyse Almeida Reis ${ }^{1}$ iD; \\ Hubert Mathias Peter Roeser ${ }^{2}$; ; Aníbal da Fonseca Santiago 3 (D) \\ ${ }^{1}$ Pós-Graduação em Engenharia Ambiental (ProAmb), Escola de Minas (EM), \\ Universidade Federal de Ouro Preto (UFOP), Campus Universitário Morro do Cruzeiro, s/n, \\ CEP 35400-000, Ouro Preto, MG, Brazil. E-mail: deysereis.reis@gmail.com \\ ${ }^{2}$ Departamento de Engenharia Ambiental (DEAMB), Escola de Minas (EM), \\ Universidade Federal de Ouro Preto (UFOP), Campus Universitário Morro do Cruzeiro, s/n, \\ CEP 35400-000, Ouro Preto, MG, Brazil. E-mail: hubert-deamb@ufop.edu.br \\ ${ }^{3}$ Departamento de Engenharia Civil (DECIV), Escola de Minas (EM), \\ Universidade Federal de Ouro Preto (UFOP), Campus Universitário Morro do Cruzeiro, s/n, \\ CEP 35400-000, Ouro Preto, MG, Brazil. E-mail: anibal@ufop.edu.br \\ "Corresponding author. E-mail: lauraifmg @ gmail.com
}

\begin{abstract}
Changes in land use and land cover in watersheds, together with population increases and urbanization of these areas, have caused negative impacts on surface water quality. Based on land-use types, we conducted a comprehensive water quality study of the Rio do Peixe watershed, a tributary of the Rio Doce River, located in the Iron Quadrangle, with different land uses/land covers. For this study, the relationship between water quality variables and land use types were examined according to the water quality index and principal components analysis. The water samples were collected from twelve stations located along the basin in two different seasons. The results of metals/semimetals concentrations reflected regional lithology, and in the case of iron, it was anthropic activities. Also, the computed water quality index values were between 26.8 and 74.9. The water quality was poor in four stations of the river basin in both seasons. Furthermore, the variables that influence water quality the most were E. coli, DBO, turbidity, nitrate, and total phosphorus. The multivariate statistics gave five principal components that together accounted for $58.3 \%$, whereas analysis of score plots identified the formation of two groups with more perceptible anthropic influence. Finally, environmental impacts of the river basin, such as deforestation, erosion, domestic sewage, and iron ore tailings, were the main factors that interfered with water quality.
\end{abstract}

Keywords: iron mining, multivariate statistics, Rio Doce.

\section{Relação entre o uso e ocupação do solo e qualidade de água numa bacia hidrográfica impactada por rejeitos de mineração de ferro e esgoto doméstico}

\section{RESUMO}

O uso e ocupação do solo, o aumento populacional e a urbanização de áreas próximas a bacias hidrográficas causam diversos impactos negativos na qualidade das águas superficiais. Diante essa assertiva, foi realizado um estudo abrangente sobre a qualidade da água na bacia hidrográfica do Rio do Peixe, tributário do Rio Doce, localizado no Quadrilátero Ferrífero e

This is an Open Access article distributed under the terms of the Creative Commons Attribution License, which permits unrestricted use, distribution, and reproduction in any medium, provided the original work is properly cited. 
que possui diferentes usos. Para a compreensão e discussão da relação entre as variáveis de qualidade da água e os tipos de uso foi calculado o índice de qualidade da água e realizada a análise de componentes principais. Para tal, foram coletadas amostras de água em doze estações amostrais localizadas ao longo da bacia em diferentes períodos sazonais. Os resultados da concentração de metais/semimetais refletiram a litologia regional, no caso das concentrações de ferro também por atividades antrópicas. Os valores do índice de qualidade da água calculados estão entre 26,8 e 74,9 e que a qualidade da água foi considerada ruim em quatro estações em ambos os períodos sazonais. Sendo que as variáveis de maior influência na qualidade da água foram E. coli, DBO, turbidez, nitrato e fósforo total. Os resultados da estatística multivariada obtida permitiram diminuir as dez variáveis iniciais em cinco componentes principais que juntos representaram 58,3\% da variância dos dados. A análise do gráfico dos escores permitiu identificar dois grupos formados onde a interferência antrópica era mais perceptível. Os impactos ambientais da bacia hidrográfica, como desmatamento, erosão, esgoto doméstico e rejeitos de mineração de ferro foram os principais fatores que interferiram na qualidade da água.

Palavras-chave: estatística multivariada, mineração de ferro, Rio Doce.

\section{INTRODUCTION}

Water quality suffers constant environmental degradation in many watersheds around the world and remains one of the major ecological concerns of contemporary society. Furthermore, the scarcity of studies that correlate land uses and water resources to the intensity of anthropogenically active regions makes it difficult to implement effective measures.

A typical example is found in the rivers within the Iron Quadrangle (IQ). The region is an important Brazilian geological geomorphological domain of mountainous relief with a significant history of gold, iron, and bauxite mining (De Vicq et al., 2015). In spite of the geological diversity, studies in the IQ have verified the contents of metals in fluvial systems derived from anthropogenic activities (Parra et al., 2012, Nascimento et al., 2018, Dos Reis et al. 2019). Several water bodies presently are faced with a decrease in water quality and quantity due to the activities of territorial occupations, the application of inappropriate farming techniques, industrialization without adequate environmental management, and the increase in population.

This type of water contamination is directly related to land use. For example, agricultural activities have a strong influence on nutrient concentrations, such as nitrogen and phosphorus levels (Arheimer and Liden, 2000). Residential areas usually contribute to urban wastewater effluent, high loads of organic matter and many contaminants of emerging concern, such as pharmaceutical wastes and personal care products, especially when the municipalities do not have wastewater treatment plants (Kilunga et al., 2017). Industrial activities are point sources of pollution that may have a large relevance. Regarding mining activities, the large amount of residues that are generated and the potential presence of trace elements in them may influence on water quality even greater.

Considering this assertion, many studies used multivariate approaches to analyze the interference of anthropogenic and natural processes in the water quality of different regions (Reis et al., 2017; Kändler et al., 2017; Khaledian et al., 2018). In these studies, the techniques of multivariate analysis were important to obtain the relevant information, aiding in the understanding of the same.

Among the exploratory analytical techniques, Principal Component Analysis (PCA) tool has been used to analyze environmental data sets, which are generally complex, due to the large number of variables involved and the strong relationship between them (Khaledian et al., 2018). 
Therefore, this study evaluated possible anthropogenic interference relationships in the quality of surface waters in the Rio do Peixe watershed, an important tributary of the Rio Doce, which has made international headlines because of the mine-tailings dam disaster in Mariana in 2015 .

\section{MATERIALS AND METHODS}

\subsection{Region of study}

The study area includes the catchment area of Rio do Peixe, located in the State of Minas Gerais, between the municipalities of Itabira and Nova Era (Figure 1). The basin is part of the Itabira Complex, a geological unit located at the northeast end of the IQ. Geologically, the study area is one of the classic areas of the Pre-Cambrian, situated in the southern end of the San Francisco Craton. Since gold exploitation around the 18th century until the present, the region has attracted large immigration movements due to its mineral potentials. Land use in the basin is characterized by $44.5 \%$ grassland areas, $27.9 \%$ forest areas, $13.8 \%$ reforested areas (pine and eucalyptus), $6.4 \%$ of mining, $5.2 \%$ urban industrial activities.

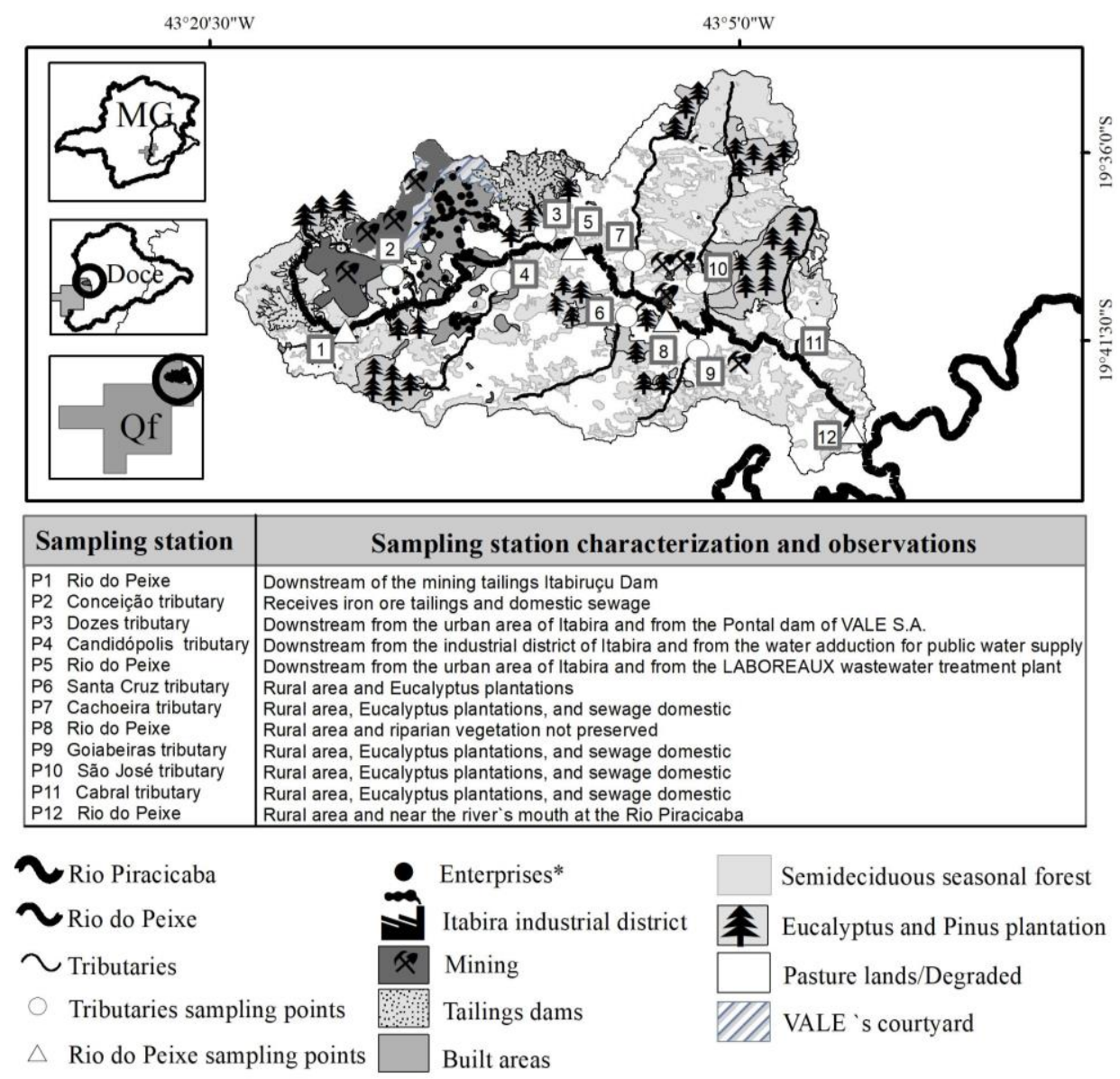

Figure 1. Locations of the sampling stations in the Rio do Peixe Basin in the Iron Quadrangle, Brazil.

The region has a population of approximately 110,000, of which $93 \%$ are located in the urban area of the city of Itabira and 7\% rural areas de Itabira and Nova Era (IBGE, 2013). Considered for its importance as the mineral production hub of Brazil, the Rio do Peixe watershed is one of the main regions for iron ore and emerald exploitation in the world. Approximately 39 million tons of iron ore and $80 \mathrm{~kg}$ of emeralds have been mined in the region (Brasil, 2015). 


\subsection{Sampling stations}

A total of 12 sampling stations were established along the waterways of the basin, of which four were situated in the main channel of the Rio do Peixe and eight in its tributaries (Figure 1). Samples were collected in the rainy (March) and dry (July) seasons in 2015, for a total of 24 water samples.

\subsection{Chemical analysis of water}

\subsubsection{Reagents and material}

All solutions prepared were analytical grade reagents and the final volumes adjusted with deionized water from the Milli-Q® system (Millipore Corporation). All glassware were previously washed with 10\% v/v nitric acid (Synth, Brazil) for $24 \mathrm{~h}$. The reagents used for chloride and total phosphorus analyses were of the Synth (Brazil) brand. Hach ${ }^{\mathrm{TM}}$ reagents were used for nitrate analysis. The analyses of total phosphorus and nitrate were done in a spectrophotometer (DR6000 ${ }^{\mathrm{TM}}$ UV VIS, Hach ${ }^{\mathrm{TM}}$ ). Equipment used in situ was a dissolved oxygen meter (Model HQ40D with an LDO101 electrode, Hach ${ }^{\mathrm{TM}}$, Germany) and a portable digital turbidimeter (Model 2100Q, $\operatorname{Hach}^{\mathrm{TM}}$ ).

For the analyses of the metal and semimetals (As, $\mathrm{Ca}, \mathrm{Cu}, \mathrm{Fe}, \mathrm{K}, \mathrm{Mn}, \mathrm{Ni}$, and $\mathrm{Zn}$ ), the following were used: a membrane (Millex HP syringe filter with Millipore Express® membrane, USA), nitric acid (Merck, Germany), inductively coupled plasma mass spectrometry (ICP MS, Agilent 7700 series, Agilent Technologies, Germany), and Standard Reference Material (SRM) 1643e for Trace Elements in Water, The National Institute of Standards and Technology (NIST), USA. The reference material used (Nist 1643e) showed a recovery rate between 90.7 and $98.1 \%$ for most evaluated elements as follows: As (95.5\%); Ca (97.6\%); Cu (95.6\%); Fe (94.9\%); K (91.9\%); Mn (93.7\%); Ni (90.7\%), and Zn (98.1\%).

\subsubsection{Analysis}

Several physicochemical variables were measured in the laboratory following the methods listed in Table 1. Also, dissolved oxygen (DO), $\mathrm{pH}$, temperature (T), and turbidity (Turb) were analyzed using portable digital probe.

For the analyses of the metal and semimetal concentrations, the water samples were filtered with a $0.45 \mu \mathrm{m}$ membrane, acidified with concentrated nitric acid and preserved at $4^{\circ} \mathrm{C}$. Subsequently, the chemical concentrations were determined using inductively coupled plasma mass spectrometry. The results were validated using a certified reference material SRM 1643e.

Table 1. Standard methods adopted for the analysis of samples.

\begin{tabular}{ll}
\hline Variables & Method used \\
\hline Biochemical Oxygen Demand (BOD) & 5-Day BOD Test, 5210B* \\
Chloride $\left(\mathrm{Cl}^{-}\right)$ & Titulometric 4500-ClB* \\
Escherichia coli $($E. coli) & Colilert@ 9223B Enzyme Substrate Coliform Test \\
Nitrate $\left(\mathrm{NO}_{3}^{-}\right)$ & Colorimetric (Hach \\
Total phosphorus (TP) & Colorimetric 4500PE* \\
Total solids (TS) & Gravimetric 2340* \\
\hline
\end{tabular}

*Source: APHA et al. (2012).

\subsection{Data analysis}

The obtained data was used to determine the water quality index (WQI) as proposed by Instituto Mineiro de Gestão das Águas (1997). WQI is defined as a rating of that reflects the composite influence of different water quality parameters as $\mathrm{BOD}, \mathrm{DO}$, E. coli, $\mathrm{NO}_{3}^{-}, \mathrm{pH}, \mathrm{T}$, TP, TS, and Turb. To calculate WQI was in accordance with IGAM instructions 
(http://portalinfohidro.igam.mg.gov.br/sem-categoria/319-indice-de-qualidade-das-aguas-iqa. Access in July 2019). The computed WQI values are classified into five categories as follows: $90<\mathrm{WQI} \leq 100$ (Excellent); 70<WQI $\leq 90$ (Good); 50<WQI $\leq 70$ (Medium); 25<WQI $\leq 50$ (Poor); $\mathrm{WQI} \leq 25$ (Very poor). The multivariate statistical procedures used was the FactorMineR by the software R@, version 3.1.3, developed by the R Foundation for Statistical. The variables used in the PCA were: $\mathrm{BOD}, \mathrm{Cl}^{-}, \mathrm{DO}$, E. coli, $\mathrm{NO}_{3}{ }^{-}, \mathrm{pH}, \mathrm{T}$, TP, TS, Turb, and $\mathrm{Fe}$.

\section{RESULTS AND DISCUSSION}

As shown in Figure 2, concentrations of the metals and semimetals measured in this study were above the limits recommended by the national regulatory agency Conselho Nacional do Meio Ambiente (CONAMA, 2005) 357/05 for arsenic (0.008 to $0.0150 \mathrm{mg} \mathrm{L}^{-1}$ ); copper $(0.014$ to $\left.0.155 \mathrm{mg} \mathrm{L}^{-1}\right)$; manganese (0.02 to $\left.13.21 \mathrm{mg} \mathrm{L}^{-1}\right)$, nickel $\left(0.012\right.$ to $\left.2.63 \mathrm{mg} \mathrm{L}^{-1}\right)$, and zinc ( 0.106 to $\left.0.445 \mathrm{mg} \mathrm{L}^{-1}\right)$. The occurrence of these chemical elements is probably from regional geology. However, mining activities in the region intensify the mobilization and availability of metals to the watershed. Iron was detected in all the samples and concentrations ranged from 0.5 to $10.2 \mathrm{mg} \mathrm{L}^{-1}$ far higher than the recommended limit of $0.3 \mathrm{mg} \mathrm{L}^{-1}$ in all the samples $(n=24)$. The occurrence of iron in the Rio do Peixe watershed is due to local geology, since iron-rich rocks are typical in the IQ. However, these elevated values exhibited a direct relationship with the tailings retention and the practice of iron ore beneficiation that have been taking place in the Rio do Peixe (Nascimento et al., 2018). Iron concentrations in the bottom sediments of the Rio do Peixe exhibit a direct relationship with the IQ geology and with anthropogenic activities. De Vicq et al. (2015), when studying basins in the state of Minas Gerais, Brazil, with similar characteristics and mining activities, also found iron enrichment in both water and sediment. According to Nascimento et al. (2018), the other metals and semimetals measured in the watershed probably originate in regional lithography, but anthropogenic activities carried out in the basin led to the mobilization and the availability of the metals for the river systems.


Figure 2. Concentrations of metals and semimetals in Rio do Peixe Basin.

\section{IPABHî}


The concentrations of the variables in the water quality measured in this study did not exceed the limits recommended by CONAMA 357/05 with the exception of biochemical oxygen demand, E. coli, dissolved oxygen, and turbidity, where values were above the limit in some sample stations (Figure 3). The lowest BOD was observed in stations P1, P4, P6, P7, P9, $\mathrm{P} 10$, and $\mathrm{P} 11$ (mean $\left.=2.2 \pm 1.2 \mathrm{mg} \mathrm{L}^{-1}\right)$. As for E. coli, the maximum was observed at stations $\mathrm{P} 2, \mathrm{P} 3, \mathrm{P} 5, \mathrm{P} 6, \mathrm{P} 8, \mathrm{P} 10$, and $\left(\right.$ mean $\left.=2.2 \pm 1.2 \mathrm{mg} \mathrm{L}^{-1}\right)$. As for $E$. coli, the maximum was observed at stations P2, P3, P5, P6, P8, P10, and P12 (mean $\left.=32.157 \pm 44.634 \mathrm{MPN} 100^{-} \mathrm{mL}^{-1}\right)$. Stations P3 (dry), P5 (both periods), and P8 in rainy period showed the minimum value of DO (mean $=3.5 \pm 0.3 \mathrm{mg} \mathrm{L}^{-1}$ ). Finally, the highest concentration of turbidity was recorded at station P2 in both periods, and in stations P8 to P12 in rainy period (mean $=928.7 \pm 260.6$ NTU). It was observed that concentrations were higher at stations that have anthropogenic influence, such as deforestation, erosion, domestic sewage, and mining waste.
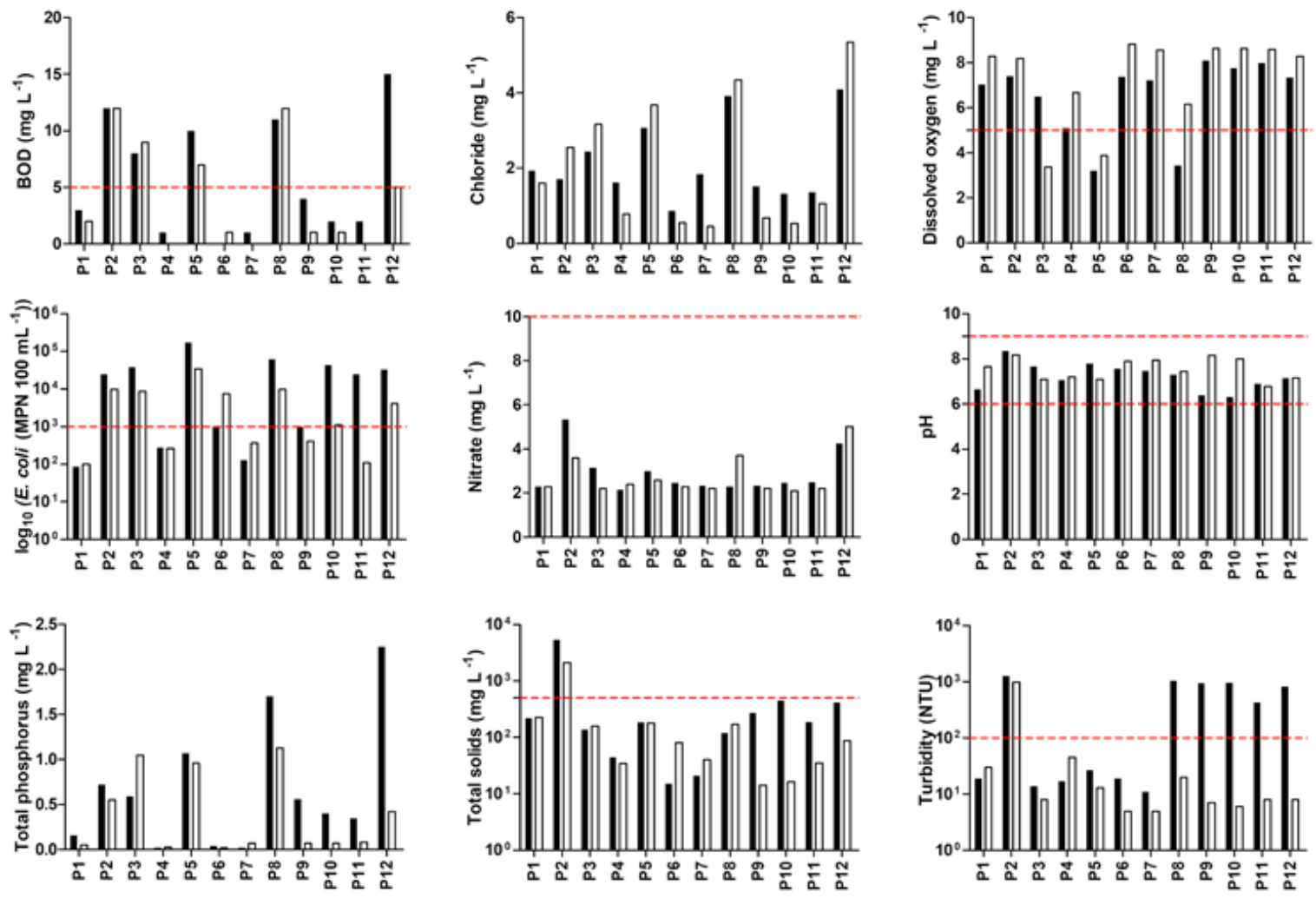

Rainy

Limits recommended by CONAMA 357/05

Figure 3. Concentrations of measured variables in waters of the Rio do Peixe Basin.

The computed WQI values are 26.8 to 74.9 in the rainy period; and 33.2 to 74.2 in the dry period. The water quality of Rio do Peixe is characterized as "poor water" in sampling stations P2, P3, P5, and P8 in both periods (Figure 4). The maximum value of WQI ("good water") was recorded at station P7 (mean $=73.1$ ), which had the lowest pollution. We believe that the decrease of the WQI on the water bodies were mainly caused by the significant presence of the bacteria due to contamination by domestic sewage, especially $E$. coli that is the most common indicator of fecal contamination. Therefore, treatment is required before use as a water supply resource.

In the urban area, E. coli bacteria persists, being a domestic wastewater characteristic from residential areas with high population density, which is the case of Itabira. These results can be explained by the dumping of domestic waste in nature of approximately $60 \%$ of the resident population of the studied watershed and this reflects in the water quality (Brasil, 2013). In the 
rural area, the presence of bacteria in surface water indicates that it has been contaminated by farm animals and other point sources, such as those reported by Al-Badaii et al. (2015). During seasons with high precipitation, the contamination of water bodies by these bacteria is increased, since the degradation situation of the watershed favors a higher load of fecal material dragged from grassland areas and rural residences. The BOD variable values negatively influenced the WQI indicates that the increased consumption of dissolved oxygen by bacteria is related to oxidative processes of degradation of high concentrations of organic matter. Menezes et al. (2016) have also reported high values of BOD when studying an urbanized watershed.

a)

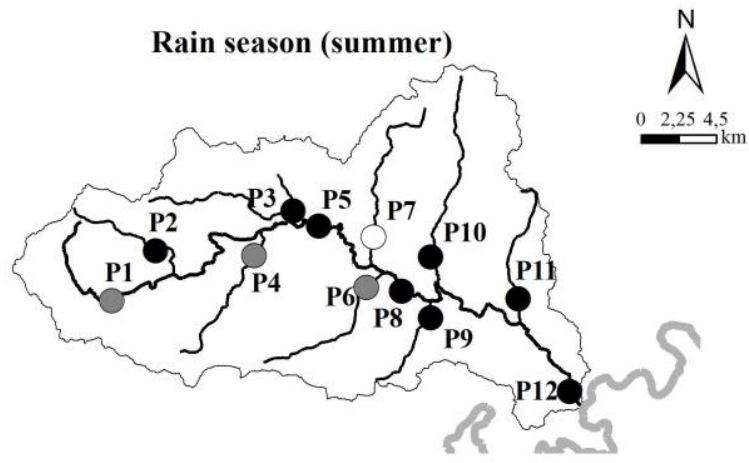

b)

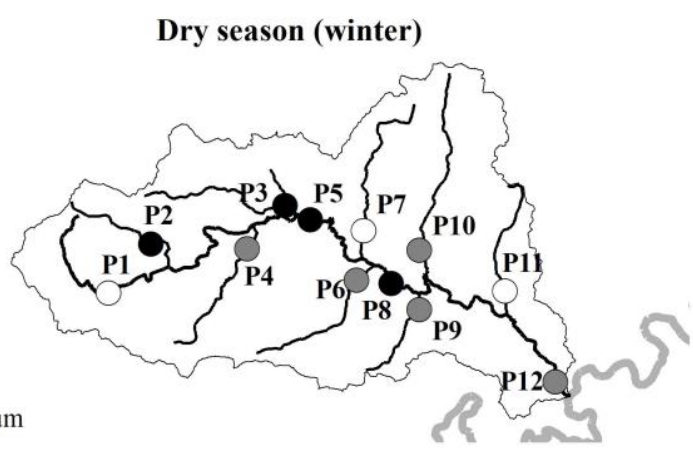

Figure 4. The water quality index of the Rio do Peixe Basin (a) rainy (b) dry.

Other variables that contributed to the decrease in WQI in the water bodies of the watershed in most sampling stations were nitrate (mean $\left.=2.8 \pm 0.9 \mathrm{mg} \mathrm{L}^{-1}\right)$ and total phosphorus (mean $=0.5 \pm 0.2 \mathrm{mg} \mathrm{L}^{-1}$ ). In urban areas the values are related to the domestic sewage. In rural areas, the occurrence of nitrate and total phosphorus in water bodies during the rainy season is associated with the lack of conservation and adequate land handling, which favors leaching and transport of fertilizers from land crops (Reis et al., 2017). According to Bu et al. (2014), the use of fertilizers based on nitrate and total phosphorus on agricultural lands with steep relief and degraded soils favors a greater contribution and enrichment of surface waters. Beef cattle and dairy livestock were frequently observed around sampling stations. We believe that their presence may have caused total phosphorus influence values to be found in these samples, as animal manure may have been carried into the river by rainwater. Similar results of total phosphorus were found in tributaries of the Doce River Oratórios River by Lacerda and Roeser (2017) and the Matipó River in Minas Gerais- Brazil by Reis et al. (2017). In both studies, the authors attributed water quality impairment to untreated sewage disposal.

The turbidity variable also influenced the drop in the WQI levels for most of the sampling stations, especially during the rainy season. This behavior could be the result of erosive processes which occurred in urban and rural areas of grasslands, soil exposure, eucalyptus cultivation, and mining activities near the watershed. During the rainy season, there is much

\section{IPABH}


undissolved matter arising from runoffs, erosion and weathering, which contributes to the high turbidity of the river. Studies in the Iron Quadrangle also found an increase of solids during the rainy season and differences in the seasons were due to impacts of mining activity (Raposo et al., 2011; Parra et al., 2012). While in urban industrial (mining operation) areas, the high turbidity values for the different seasons of the year were directly associated with the residues escaping from the dams and containment basin of the mining companies located upstream of the stations (Nascimento et al., 2018). Particularly, sampling station P2 experienced more mining influences, hence it showed high turbidity values: 1281 NTU in the rainy period and 990 NTU in the dry season.

The application of PCA to the initial ten variables and iron used for the calculation of WQI, gave two principal components (PC) that together accounted for $58.30 \%$ of the total data variation. The PC1 accounted for $35.65 \%$ and PC2 $22.65 \%$ of the data set, respectively (Table 2). The distribution of the samples by principal component analysis (PCA) is presented in Figure 5, where we have the graph of the values for $\mathrm{PC}_{1}$ vs $\mathrm{PC}_{2}$. The stations with the letter "R" refer to the rainy season and the letter "D" the dry season.

Table 2. Component loadings of the monitored variables for the principal components (PC) for surface water.

\begin{tabular}{lll}
\hline Variable & PC1 & PC2 \\
\hline $\mathrm{BOD}$ & 0.81 & -0.26 \\
$\mathrm{Cl}^{-}$ & 0.52 & -0.61 \\
$\mathrm{DO}$ & -0.23 & 0.83 \\
E. coli & 0.43 & -0.61 \\
$\mathrm{NO}^{-}$ & 0.80 & 0.09 \\
$\mathrm{pH}$ & 0.25 & 0.28 \\
$\mathrm{~T}$ & 0.33 & -0.28 \\
$\mathrm{TP}$ & 0.65 & 0.41 \\
$\mathrm{TS}$ & 0.75 & 0.46 \\
$\mathrm{Turb}$ & 0.72 & 0.33 \\
$\mathrm{Fe}$ & 0.63 & 0.53 \\
\hline \% of variation explained & 35.65 & 22.65 \\
\hline \% accumulated & 35.65 & 58.30 \\
\hline
\end{tabular}
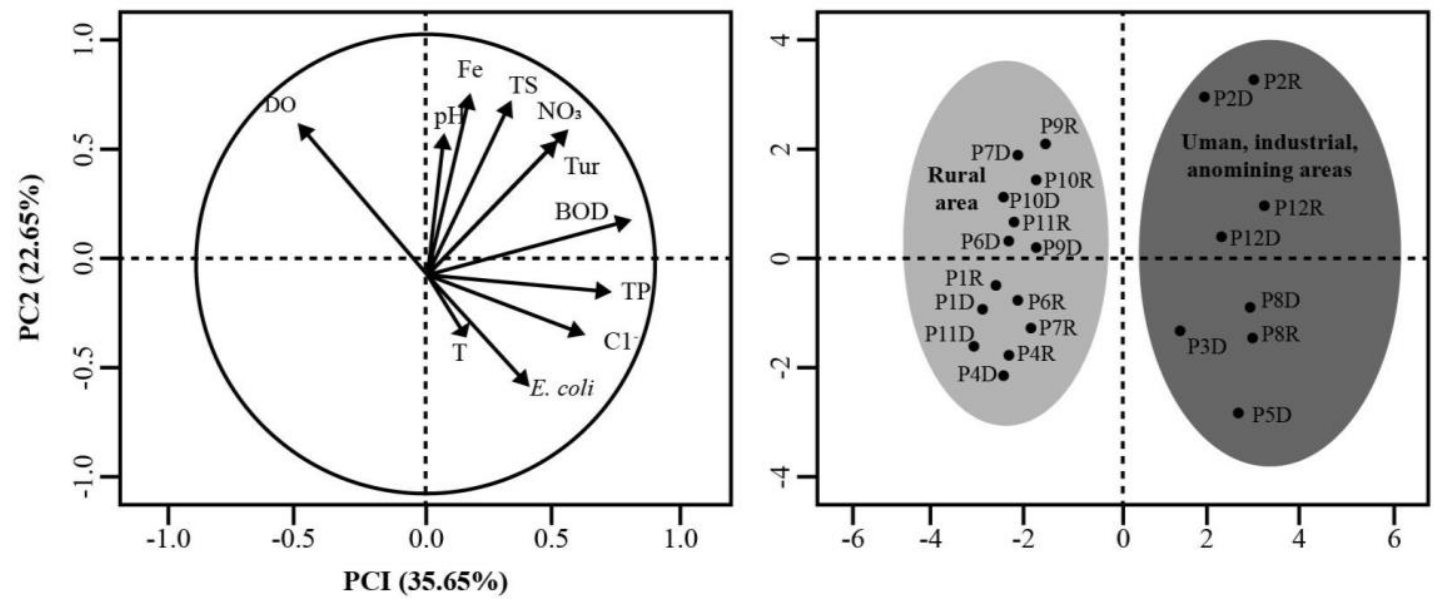

Figure 5. Principal component analysis of water quality variables.

The PCA separated the data into two groups. Group 1, formed by the sampling stations in tributaries and located in rural areas, such as stations P1, P4, P6, P7, P9, P10, and P11, was 
positively influenced by the presence of dissolved oxygen (Figure 5). This group can be considered an ecological response to some changes introduced in the system caused by natural factors or anthropogenic contamination, such as grassland, agricultural, and sewage.

Group 2 is composed of the sampling stations that receive contributions from urban industrial activities and mining areas such as: P2, P3, P5, P8, and P12. These stations were most influenced by the variables: temperature, $\mathrm{Cl}^{-}, E$. coli, $\mathrm{pH}, \mathrm{BOD}, \mathrm{NO}_{3}^{-}$, TP, Tur, and TS. The occurrence of such variables is related to the degradation of soils, domestic sewage and iron ore mining. The sampling stations P3, P5, and P8 were directly affected by the sewage from the main urban area of Itabira, while sampling station P2 received substantial contributions of ore tailings leaked from mining tailings contention dams. These caused the elevated values for turbidity and total solids. Besides the tailings, the sampling station P2 showed high contents of E. coli.

This could be related to the constant loads of sewage received from residential areas. The analysis carried out for the Rio do Peixe Basin stations demonstrates severe fecal contamination of the water. The problem had been reported for the Doce River watershed since the 1990s (IGAM, 1997). In 2018, Drummond et al. (2018) attributed the bacterial contamination in the Rio Xopotó, tributary of the Rio Doce, during the spring to the introduction of untreated domestic effluents from the riparian residences and the presence of animals (cattle and pigs), even within the river.

\section{CONCLUSIONS}

In this research, the potential of the multivariate approach for the understanding of water quality dynamics in watersheds was verified. It is important to note that, even with the use of fewer variables, it was possible to identify important influences of anthropic activities on the results of biodegradable oxygen demand, dissolved oxygen, E. coli, iron, and turbidity. The results of WQI showed that the river can be classified between "poor water" and "good water".

The PCA application to 10 variables analyzed for surface waters showed two major components that together accounted for $57.3 \%$, whereas the analysis of score plots identified the formation of two groups with anthropic interference being more perceptible.

Finally, the environmental impacts of Rio do Peixe watershed, including deforestation, erosion, domestic sewage, and iron ore tailings were the main factors that affected the river's water quality.

\section{ACKNOWLEDGEMENTS}

This study was made possible by support from the Fundação de Amparo à Pesquisa do Estado de Minas Gerais (FAPEMIG), the Conselho Nacional de Desenvolvimento Científico e Tecnológico (CNPq), and the Coordenação de Aperfeiçoamento de Pessoal de Nível Superior (CAPES) for which we are deeply thankful. We also thank the Laboratório de Geoquímica Ambiental at Federal University of Ouro Preto for the ICP analysis, as well as Fundação Gorceix.

\section{REFERENCES}

\section{APHA; AWWA; WEF. Standard Methods for the examination of water and wastewater.} 22nd ed. Washington, 2012.

Al-BADAII, F.; SHUHAIMI-OTHMAN, M. Water Pollution and its Impact on the Prevalence of Antibiotic-Resistant E. coli and Total Coliform Bacteria: A Study of the Semenyih 
River, Peninsular Malaysia. Water Quality, Exposure and Health, v. 7, p. 319-330, 2015. https://doi.org/10.1007/s12403-014-0151-5

ARHEIMER, B.; LIDEN, R. Nitrogen and phosphorus concentrations from agricultural catchments-influence of spatial and temporal variables. Journal of Hydrology, v. 227, n. 1-4, p. 140-159, 2000. https://doi.org/10.1016/S0022-1694(99)00177-8

BRASIL. Departamento Nacional de Produção Mineral. Legislação. 2015. Available at: http://www.dnpm.gov.br/conteudo.asp?IDSecao=67\&IDPagina=84\&IDLegislacao=52. Access: 07 Jan. 2018.

BRASIL. Ministério das Cidades. Sistema Nacional de Informações sobre Saneamento (SNIS). Aplicativo Série Histórica. 2013. Available at: http://www.snis.gov.br. Access: 10 Jan. 2019.

BU, H. et al. Relationships between land use patterns and water quality in the Taizi River basin, $\begin{array}{llllll}\text { China. Ecological Indicators, } & \text { v. } 41, \quad \text { p. } & \text { 187-197, }\end{array}$ https://doi.org/10.1016/j.ecolind.2014.02.003

CONAMA (Brasil). Resolução $\mathrm{n}^{\circ} 357$ de 17 de março de 2005. Dispõe sobre a classificação dos corpos de água e diretrizes ambientais para o seu enquadramento, bem como estabelece as condições e padrões de lançamento de efluentes, e dá outras providências. Diário Oficial [da] União: seção 1, Brasília, DF, n. 053, p. 58-63, 18 mar. 2005.

DE VICQ, R. et al. Iron Quadrangle stream sediments, Brazil: geochemical maps and reference values. Environmental Earth Sciences, v. 74, n. 5, p. 4407-4417, 2015. https://doi.org/10.1007/s12665-015-4508-2

DOS REIS, D. A. et al. The Relationship Between Human Adenovirus and Metals and Semimetals in the Waters of the Rio Doce, Brazil. Archives of environmental

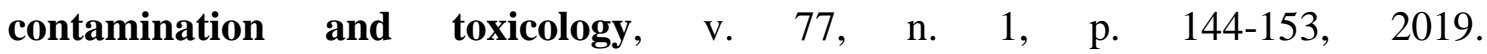
https://doi.org/10.1007/s00244-019-00625-w

DRUMOND, S. N. et al. Identificação molecular de Escherichia coli diarreiogênica na Bacia Hidrográfica do Rio Xopotó na região do Alto Rio Doce. Engenharia Sanitária e Ambiental, v. 23, p. 579-590, 2018.

IBGE. Censo. 2013. Available at: https://cidades.ibge.gov.br/. Access: 05 Jan. 2018.

IGAM. Relatórios de qualidade de água. 1997. Available at: http://portalinfohidro.igam.mg.gov.br/publicacoes-tecnicas/qualidade-dasaguas/qualidade-das-aguas-superficiais/relatorios-de-avaliacao-de-qualidade-das-aguassuperficiais/relatorios-anuais/1997/6104-relatorio-qualidade-aguas-superf-minasgerais1997. Access: 15 Jan. 2018.

KÄNDLER, M. et al. Impact of land use on water quality in the upper Nisa catchment in the Czech Republic and in Germany. Science of The Total Environment, v. 586, p. 13161325, 2017. https://doi.org/10.1016/j.scitotenv.2016.10.221

KHALEDIAN, Y. et al. Assessment of water quality using multivariate statistical analysis in the Gharaso River, Northern Iran. Urban ecology, water quality and climate change, v. 84, p. 227-253, 2018. https://doi.org/10.1007/978-3-319-74494-0_18

KILUNGA, P. I. et al. Accumulation of toxic metals and organic micro-pollutants in sediments from tropical urban rivers, Kinshasa, Democratic Republic of the Congo. Chemosphere, v. 179, p. 37-48, 2017. https://doi.org/10.1016/j.chemosphere.2017.03.081 
LACERDA, F. M.; ROESER, H. M.P. Análise geoquímica e ambiental para descrição da bacia do Rio Oratórios (MG). Geochimica Brasiliensis, v. 28, p. 227-236, 2017.

NASCIMENTO, L. P. et al. Avaliação geoquímica de metais em sistemas fluviais afetados por atividades antrópicas no Quadrilátero Ferrífero. Engenharia Sanitária e Ambiental, v. 23, n. 4, 2018.

MENEZES, J. P. C. et al. Relação entre padrões de uso e ocupação do solo e qualidade da água em uma bacia hidrográfica urbana. Revista de Engenharia Sanitária e Ambiental, v. 21, n. 3, p. 519-534, 2016.

PARRA, R. R. et al. Influência antrópica na geoquímica de água e sedimentos do Rio Conceição, Quadrilátero Ferrífero, Minas Gerais-Brasil. Geochimica Brasiliensis, v. 21, n. 1, p. 36-49, 2012.

RAPOSO, A. A.; BARROS, L. F. de P.; MAGALHÃES JÚNIOR, A. P. O uso de taxas de turbidez da bacia do alto rio das Velhas-Quadrilátero Ferrífero/MG-como indicador de pressões humanas e erosão acelerada. Revista de Geografia, v. 27, n. 3., p. 34-50, 2011.

REIS, D. A. dos et al. Influência dos fatores ambientais e antrópicos nas águas superficiais no rio Matipó, afluente do rio Doce. Revista de Gestão de Águas da América Latina, v. 14, n. 2, 2017. 